Indonesian Journal of Biotechnology, December, 2014

Vol. 19, No. 2, pp.121-128

\title{
Genetic Determination and Clonal Relationships of Staphylococcus aureus Isolated from Dairy Cows in Baturraden, Central Java, Indonesia
}

\author{
Fatkhanuddin Aziz ${ }^{1)}$, Siti Isrina Oktavia Salasia*2), and Mitra Slipranata ${ }^{2)}$
}

\author{
${ }^{1)}$ Graduate School of Biotechnology \\ 2)Department of Clinical Pathology, Faculty of Veterinary Medicine, Gadjah Mada University, \\ Indonesia.
}

\begin{abstract}
Staphylococcus aureus is a relatively clonal microorganism that causes subclinical and clinical mastitis. Cases of mastitis in cows at Baturraden are leading to significant and ongoing problems due to reduced production and lower milk quality. This study was designed to identify which of selected virulence determinant genes of S. aureus are involved in the Baturraden infection, and to determine the clonal relationship among these isolates. Seventeen isolates were identified as S. aureus based on their biochemical properties and species specificity for $23 \mathrm{~S}$ rRNA and nuc genes. S. aureus isolates were genotypically characterized for the selected virulence determinants: $c o a, c l f \mathrm{~A}, f n b \mathrm{~A}, f n b \mathrm{~B}, c a p 5$, spa IgG and spa X-region genes. Clonal relationship analysis among isolates was carried out using AFLP and results compared with previously confirmed relationships between selected $S$. aureus isolated from other regions. The results show that eight isolates contain all the genes, but six isolates lack fnbB and two isolates lack cap5 genes. AFLP analysis showed that all isolates of $S$. aureus originating from cows in Baturraden belong to one cluster. This study provides additional knowledge about $S$. aureus infection in Baturraden cows, including the number of virulence determinant genes that may play a role in pathogenicity.
\end{abstract}

Keywords: Staphylococcus aureus, virulence determinants, dairy cows, PCR, AFLP

\section{Introduction}

Staphylococcus aureus (S. aureus) is a relatively clonal microorganism that causes subclinical and clinical mastitis (Melles et al. 2009; Salasia et al., 2011). This disease causes significant economic losses in dairy farms due to decrease in milk production, shorter lactation times and increased costs for treatment and stock replacement (Halasa et al., 2007; Nielsen, 2009). S. aureus is also known as an important food-borne pathogen which has the ability to produce various virulence factors and a wide range

\section{*Corresponding author :}

Siti Isrina Oktavia Salasia

Department of Clinical Pathology, Faculty of Veterinary Medicine, Gadjah Mada University, Yogyakarta, Indonesia, Tel: +62274560862; Fax: +62274560861, E-mail: isrinasalasia@yahoo.com of extracellular proteins that contribute to the pathogenicity of the organism (Nashev et al., 2004).

Cases of subclinical and clinical mastitis of cows are occuring at Baturraden, one of the national dairy cow centres in Indonesia, causing significant and ongoing problems due to decreased production and lower quality of milk (Agus, 1991). S. aureus is recognized as a major pathogen causing subclinical and clinical intramammary infections in dairy cows in Indonesia (Abrar et al., 2012). Therefore, this site provides an excellent opportunity to investigate the characteristics of Indonesian strains of $S$. aureus.

Tato (2012) has proposed that, in order to develop strategies to control $S$. aureus infection from various countries or areas, we need the ability to map the virulence 
determinants of bacteria, as well as the capability of the bacteria to survive the heavy pressure of various antibiotics, geographical conditions, and adaptation to environments. Salasia et al. (2011) reported that molecular typing of $S$. aureus and determining the clonal relationship between isolates has proved useful for epidemiological studies. Therefore, mapping the virulence determinant genes and clonal relationship patterns of $S$. aureus isolates from Baturraden could be important in trying to address the problems there.

The present study was designed to identify which of selected virulence determinant genes of $S$. aureus act in the pathogenicity of the $S$. aureus infection in Baturraden, and to determine the clonal relationship among these isolates. The results may contribute not only to knowledge of $S$. aureus in specific locations, but also to potential control strategies for staphylococcal mastitis in the future.

\section{Materials and Methods}

\section{Milk samples and bacterial isolation}

Milk samples were collected aseptically by hand milking into sterile $15 \mathrm{ml}$ tubes from seventeen dairy cows from Balai Besar Pembibitan Ternak Unggul (BBPTU) Baturraden, Central Java, Indonesia. Milk samples were placed in an ice box for transport to the Faculty of Veterinary Medicine, Gadjah Mada University, for isolation of strains. The strains were identified as $S$. aureus by their properties in mannitol salt agar, Gram staining, and biochemical assays, as described by Ariyanti et al. (2011) and Salasia et al. (2011). The strains were then identified genotypically by PCR amplification of the $23 S$ rRNA and thermonuclease nuc genes (Salasia et al., 2011). The reaction mixture $(30 \mu \mathrm{L})$ for PCR contained $1 \mu \mathrm{L}$ of $10 \mathrm{pmol}$ of the forward and reverse primers (Table 1; Invitrogen, USA), $14 \mu \mathrm{L}$ PCR mix (Roche, Germany) containing Taq DNA polymerase, $\mathrm{MgCl}_{2}$, and dNTPs, $5 \mu \mathrm{L}$ of DNA template, and $9 \mu \mathrm{L}$ molecular grade water. The DNA of the isolates was prepared with the DNeasy blood and tissue kit (Qiagen, Germany) following the manufacturer's directions. The amplification of the genes was carried out with a thermal cycler (Mastercycler; Eppendorf, Germany); the thermal cycler programs are shown in Table 1.

\section{Isolation of DNA and purification}

Chrosomal DNA from $S$. aureus was isolated by a DNeasy blood and tissue kit (Qiagen, Germany) according to the manufacturer's protocol. The bacterial strains were cultivated on blood agar (Oxoid, Germany) containing 5\% defibrinated sheep blood for $24 \mathrm{~h}$ at $37^{\circ} \mathrm{C}$ (Salasia et al., 2004). S. aureus colonies (5-10) were suspended with $180 \mu \mathrm{L}$ TE buffer $(10 \mathrm{mM}$ Tris- $\mathrm{HCl}$ and $1 \mathrm{mM}$ EDTA [pH 8]) containing $5 \mu \mathrm{L}$ lysostaphin (1.8 U/ $\mu \mathrm{L}$; Sigma, USA) in 2 -mL microfuge tubes. The suspension was incubated for $1 \mathrm{~h}$ at $37^{\circ} \mathrm{C}$, and $25 \mu \mathrm{L}$ of proteinase $\mathrm{K}(14.8 \mathrm{mg} /$ mL; Sigma, USA) and $200 \mu \mathrm{L}$ of AL buffer (containing reagents AL1 and AL2 from the kit; Qiagen, Germany) was then added. The suspensions were incubated for $30 \mathrm{~min}$ at $56^{\circ} \mathrm{C}$, and then for $10 \mathrm{~min}$ at $95^{\circ} \mathrm{C}$ before being spun at $6,000 \times \mathrm{g}$ for a few seconds. Ethanol $(420 \mu \mathrm{L})$ was added to each sample and the mixture placed in a spin DNeasy column. After centrifugation at $6,000 \times \mathrm{g}$ for $1 \mathrm{~min}$, the spin columns were placed in a clean collection tube and the sample was washed twice with $500 \mu \mathrm{L}$ of AW buffer (Qiagen, Germany). After the second wash and centrifugation at $6,000 \times \mathrm{g}$ for $3 \mathrm{~min}$, the DNeasy spin columns were placed in a clean 2-mL microfuge tube, and the DNA was eluted twice with $200 \mu \mathrm{L}$ and $100 \mu \mathrm{L}$ of AE buffer (Qiagen, Germany). DNA was stored at $-20^{\circ} \mathrm{C}$ (Salasia et al. (2011).

\section{Genotype characterization}

A PCR method was used to identify the genetic determinants of selected virulence factors. The oligonucleotide primers used amplified the virulence genes encoded by coa, clfA, fnbA, fnbB, cap5, spa IgG and spa 
Table 1. Oligonucleotide primers and PCR programs used to amplify the genes encoding 23S rRNA, thermonuclease and selected staphylococcal virulence determinant genes identified from literature

\begin{tabular}{|c|c|c|c|}
\hline Genes & Sequence & Program* & Refference \\
\hline 23S rRNA & $\begin{array}{l}\text { 5'ACG GAG TTA CAA AGG ACG AC 3' } \\
\text { 3'AGC TCA GCC TTA ACG AGT AC 5' }\end{array}$ & 1 & Straub et al., 1999 \\
\hline nuc & $\begin{array}{l}\text { 5'GCG ATT GAT GGT GAT ACG GTT 3' } \\
\text { 3'ACG CAA GCC TTG ACG AAC TAA AGC 5' }\end{array}$ & 2 & Salasia et al., 2011 \\
\hline clfA & $\begin{array}{l}\text { 5'GGC TTC AGT GCT TGT AGG } \\
\text { 3'TTT TCA GGG TCA ATA TAA GC 5' }\end{array}$ & 3 & Salasia et al., 2011 \\
\hline coa & $\begin{array}{l}\text { 5'ATA GAG ATG CTG GTA CAG G 3' } \\
\text { 3' GCT TCC GAT TGT TCG ATG C 5' }\end{array}$ & 4 & Salasia et al., 2011 \\
\hline$f n b \mathrm{~A}$ & $\begin{array}{l}\text { 5' GCG GAG ATC AAA GAC AA 3' } \\
\text { 3' CCA TCT ATA GCT GTG TGG 5' }\end{array}$ & 5 & Salasia et al., 2004 \\
\hline$f n b B$ & $\begin{array}{l}\text { 5' GGA GAA GGA ATT AAG GCG 3' } \\
\text { 3' GCC GTC GCC TTG AGC GT 5' }\end{array}$ & 5 & Salasia et al., 2004 \\
\hline cap5 & $\begin{array}{l}5^{\prime} \text { ATG ACG ATG AGG ATA GCG 3' } \\
3^{\prime} \text { CTC GGA TAA CAC CTG TTG C 5' }\end{array}$ & 6 & Salasia et al., 2011 \\
\hline spa IgG & $\begin{array}{l}\text { 5' CAC CTG CTG CAA ATG CTG CG 3' } \\
\text { 3' GGC TTG TTG TTG TCT TCC TC 5' }\end{array}$ & 7 & Salasia et al., 2004 \\
\hline $\begin{array}{l}\text { spa } \\
\text { X-region }\end{array}$ & $\begin{array}{l}\text { 5' CAA GCA CCA AAA GAG GAA 3' } \\
\text { 3' CAC CAG GTT TAA CGA CAT 5' }\end{array}$ & 8 & Salasia et al., 2004 \\
\hline $\begin{array}{l}\text { * } 1: 30 \text { cycles } \\
\text { sec, } 72^{\circ} \mathrm{C} \text { fo } \\
\text { for } 60 \mathrm{sec}, \\
\text { sec; } 6: 30 \mathrm{c}\end{array}$ & $\begin{array}{l}94^{\circ} \mathrm{C} \text { for } 120 \mathrm{sec}, 64^{\circ} \mathrm{C} \text { for } 40 \mathrm{sec}, 72^{\circ} \mathrm{C} \text { for } 75 \mathrm{sec} \\
0 \mathrm{sec} ; 3: 35 \mathrm{cycles} \text { of } 94^{\circ} \mathrm{C} \text { for } 60 \mathrm{sec}, 57^{\circ} \mathrm{C} \text { for } \\
\mathrm{C} \text { for } 60 \mathrm{sec}, 72^{\circ} \mathrm{C} \text { for } 60 \mathrm{sec} ; 5: 30 \mathrm{cycles} \text { of } 94 \\
\text { es of } 94^{\circ} \mathrm{C} \text { for } 60 \mathrm{sec}, 54^{\circ} \mathrm{C} \text { for } 45 \mathrm{sec}, 72^{\circ} \mathrm{C} \text { for } 6 \\
\mathrm{C} \text { for } 60 \mathrm{sec} ; 8: 33 \mathrm{cycles} \text { of } 94^{\circ} \mathrm{C} \text { for } 60 \mathrm{sec}, 53^{\circ} \mathrm{C}\end{array}$ & $\begin{array}{l}7 \text { cycles } \\
72^{\circ} \mathrm{C} \text { for } \\
60 \mathrm{sec}, 5 \\
7: 33 \mathrm{cyc}\end{array}$ & $\begin{array}{l}\text { for } 60 \mathrm{sec}, 55^{\circ} \mathrm{C} \\
\text { ec; } 4: 30 \text { cycles of } \\
\text { for } 45 \mathrm{sec}, 72^{\circ} \mathrm{C} \text {. } \\
94^{\circ} \mathrm{C} \text { for } 60 \mathrm{sec} \text {, }\end{array}$ \\
\hline
\end{tabular}

$\mathrm{X}$-region genes. The sequences of the primers and PCR conditions are shown in Table 1.

\section{Amplified Fragment Length Polymorphism (AFLP) analysis}

The DNA of the isolates was prepared with the DNeasy blood and tissue kit (Qiagen, Germany) as per by the manufacturer's protocol. An AFLP analysis was performed according to Boerema et al. (2006) and Salasia et al. (2011). Genomic DNA (5 $\mu \mathrm{L})$ was digested overnight $(16 \mathrm{~h})$ at $37^{\circ} \mathrm{C}$ with $10 \mathrm{U}$ of HindIII (Invitrogen, USA) and $5 \mathrm{mM}$ spermidine trihydrochloride (Sigma, USA) added to a final volume of $20 \mu \mathrm{L}$. The $5 \mu \mathrm{L}$ of digested DNA was added to a ligation reaction containing $0.2 \mu \mathrm{g}$ of each adapter oligonucleotide (ADH-1 ACG GTA TGC GAC AG and ADH-2 AGC TCT GTC GCA TAC CGT GAG) (Invitrogen, USA) and 1 $\mathrm{U}$ of T4 DNA ligase (Invitrogen, USA) in a final volume of $20 \mu \mathrm{L}$, and incubated for $4 \mathrm{~h}$ at room temperature (approximately $20^{\circ} \mathrm{C}$ ). The ligated DNA samples were heated for $10 \mathrm{~min}$ at $80^{\circ} \mathrm{C}$ to inactivate the T4 ligase and then diluted $1: 5$ in sterile water. PCR reactions were performed in a total volume of $50 \mu \mathrm{L}$ containing $2.5 \mu \mathrm{L}$ of template DNA, $200 \mu \mathrm{M}$ of dNTPs (Roche, Germany), $1 \mu \mathrm{L}$ of HI-X primer (GGT ATG CGA CAG AGC TTX, where $X=A, T, G$ or $\mathrm{C} ; 100 \mathrm{pmol} / \mu \mathrm{L}$; Invitrogen, USA), and 1 $\mu \mathrm{L}(5 \mathrm{U})$ of Taq DNA polymerase (Roche, Germany) in $1 \times$ PCR buffer provided by the manufacturer (Roche, Germany). Each HI-X primer was used in four separate PCR reactions. Amplification was performed in a thermal cycler (Eppendorf, Germany). After initial denaturation for $4 \mathrm{~min}$ at $94^{\circ} \mathrm{C}$, target gene fragments were amplified for 33 cycles. Each cycle consisted of a denaturation step for $1 \mathrm{~min}$ at $94^{\circ} \mathrm{C}$, an annealing step for $1 \mathrm{~min}$ at $60^{\circ} \mathrm{C}$, and an extension for $2.5 \mathrm{~min}$ at $72^{\circ} \mathrm{C}$. An additional base pair was incorporated into each adapter oligonucleotide in the restriction site in order to eliminate it after 
the ligation reaction. The PCR products were separated by gel electrophoresis in a $1.5 \%(\mathrm{w} / \mathrm{v})$ agarose gel (Roth, Germany) in $0.5 \times$ TBE buffer (containing a mixture of Tris base, boric acid and EDTA). A 1-kb Plus DNA ladder (Invitrogen, USA) was used as a size marker. The resulting bands were visualized using ethidium bromide staining under UV transillumination and the gel images were evaluated visually. AFLP patterns were analyzed using NTSYSpc 2.1 software (Applied Biostatistic, New York). Dendrograms were obtained with the average linkage method (unweighted pair group average method, UGPMA) following Boerema et al. (2006) and Salasia et al. (2011).

\section{Results and Discussion}

Seventeen isolates were identified as $S$. aureus (Table 2). All 17 cultures were Gram positive and positive for catalase, coagulase, VP test, and clumping factor reaction on microscope slides (data not shown). Eight isolates contained all the coa, nuc, clfA, fnbA, $f n b \mathrm{~B}, c a p 5$, spa IgG, and spa X-region genes of various sizes, but six isolates lacked $f n b \mathrm{~B}$ and two isolates lacked cap5 genes (Table 2).

The proteins encoded by coa, fnbA, clfA and $f n b \mathrm{~B}$, spa IgG and the spa X-region contribute to the avoidance mechanism of $S$. aureus against the host immune system. These genes, except the coa gene, encode adhesin proteins that can bind to fibrinogen, elastin and fibronectin, mainly on the surface of epithelial cells. This binding is an important stage in the process of colonization and infection through the attachment of bacteria to host cells and extracellular matrix. The ability of $S$. aureus to bind fibrinogen could inhibit the process of opsonisation of $S$. aureus (Pratomo et al., 2012).

$S$. aureus produces an enzyme called coagulase encoded by the coa gene. This is a polypeptide that binds to and activates prothrombin, thereby converting fibrinogen to fibrin and promoting clotting of plasma or blood and leading to the formation of abscesses (Cheng et al., 2010). Seventeen isolates in this study contain this gene, with polymorphism in size; two isolates have sizes of $600 \mathrm{bp}$ and the others are $900 \mathrm{bp}$ (Table 2). da Silva and da Silva (2005) and Saei et al. (2009) reported that the coa gene can be used as an epidemiological marker for typing $S$. aureus isolates.

Amplification of spa IgG and spa $X$-region genes in the present study showed the same amplicon sizes as the previous study by Salasia et al. (2004). However, the current study showed the polymorphism bands of the spa X-region gene for two isolates with sizes of $100 \mathrm{bp}$ and for the other 15 isolates $200 \mathrm{bp}$ (Table 2). The spa-X region exists in all strains of $S$. aureus, where $X$-region indicates tandem repeats with sizes ranging from 24-26 bp in conserved areas in the genome of $S$. aureus. Protein A, encoded by spa IgG and spa X-region, acts to bind the Fc region of IgG, which has an important role in the phagocytosis mechanism through the classical pathway of complement activation (Atkins et al., 2008).

Capsular polysaccharides of $S$. aureus also play an important role in the pathogenesis (Salasia et al., 2004), causing invasive disease (O'Riordan and Lee, 2004) by protecting the bacteria from phagocytosis of leukocytes and facilitating attachment to host epitel and endotel cells. The study shows that $15 S$. aureus isolates (88\%) have a cap5 gene. This result agrees with the previous finding of Salasia et al. (2011), who reported that most $S$. aureus isolated from cows have cap5 genes.

Amplification of the 23S rRNA, nuc, clfA, $f n b \mathrm{~A}, f n b \mathrm{~B}, c a p 5$ and spa IgG genes produced amplicons with approximate sizes of 1250, 1050, 300, 1300, 900, 880 and 900 $\mathrm{bp}$, respectively. The coa gene and the spa $X$-region showed polymorphism bands. The size of the coa gene in two isolates was 600 bp and in the other 15 isolates was 900 bp; similarly the spa X-region gene showed two sizes: $100 \mathrm{bp}$ in the same isolates as they had smaller size for the coa gene and $200 \mathrm{bp}$ in the other isolates (Figure 1 and Table 2). 


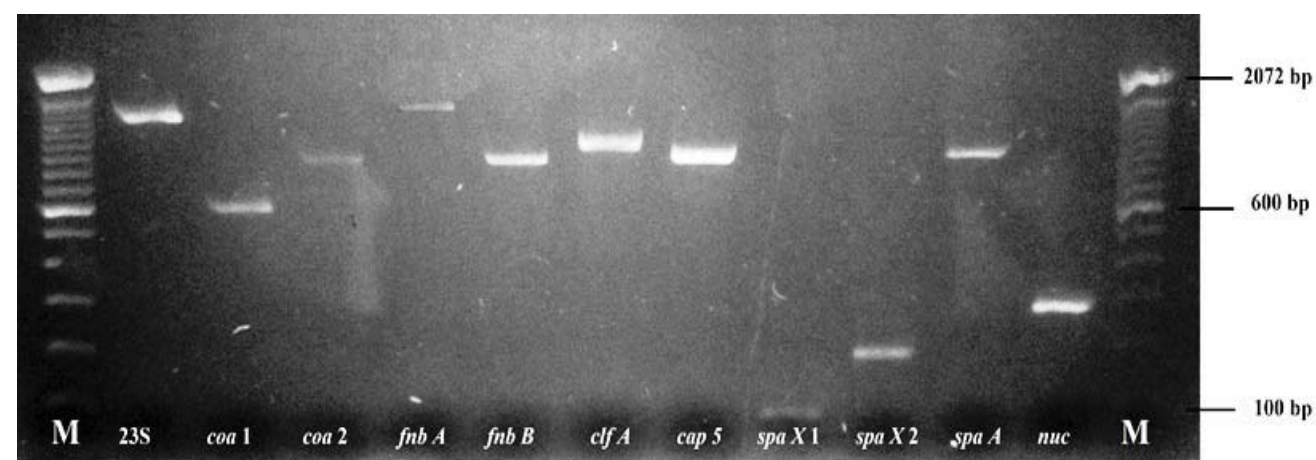

Figure 1. Agarose gel electrophoresis image of virulence determinant genes of S. aureus. $\mathrm{M}=100$ bp DNA marker (Invitrogen).

Table 2. Genotypic characterization of 17 S. aureus isolates from dairy cows in Baturraden, Central Java, Indonesia

\begin{tabular}{|c|c|c|c|c|c|c|c|c|c|c|}
\hline No & $\begin{array}{c}\text { Isolate } \\
\text { code }\end{array}$ & $\begin{array}{c}\text { 23S r RNA } \\
\text { (1250bp) }\end{array}$ & $\begin{array}{c}c o a \\
(900 \mathrm{bp})\end{array}$ & $\begin{array}{c}n u c \\
(300 \mathrm{bp})\end{array}$ & $\begin{array}{c}\text { clfA } \\
(1050 \mathrm{bp})\end{array}$ & $\begin{array}{c}f n b \mathrm{~A} \\
(1300 \mathrm{bp})\end{array}$ & $\begin{array}{c}f n b \mathrm{~B} \\
(900 \mathrm{bp})\end{array}$ & $\begin{array}{c}\text { cap5 } \\
\text { (880bp) }\end{array}$ & $\begin{array}{c}\text { spa IgG } \\
(900 \mathrm{bp})\end{array}$ & $\begin{array}{c}\text { spa X region } \\
(200 \mathrm{bp})\end{array}$ \\
\hline 1 & BR03b & + & 2 & + & + & + & + & + & + & + \\
\hline 2 & BR39a & + & 2 & + & + & + & + & + & + & + \\
\hline 3 & BR13a & + & 2 & + & + & + & + & + & + & + \\
\hline 4 & BR00b & + & 2 & + & + & + & + & + & + & + \\
\hline 5 & BR90c & + & 2 & + & + & + & + & + & + & + \\
\hline 6 & $\mathrm{BR} 02 \mathrm{a}$ & + & 2 & + & + & + & + & + & + & + \\
\hline 7 & BR67c & + & 2 & + & + & + & + & + & + & + \\
\hline 8 & BR38d & + & 2 & + & + & + & + & + & + & + \\
\hline 9 & BR30d & + & 2 & + & + & + & - & + & + & + \\
\hline 10 & $\mathrm{BR} 40 \mathrm{c}$ & + & 2 & + & + & + & - & + & + & + \\
\hline 11 & BR82a & + & 2 & + & + & + & - & + & + & + \\
\hline 12 & BR75a & + & 2 & + & + & + & - & + & + & + \\
\hline 13 & BR78a & + & 2 & + & + & + & - & + & + & + \\
\hline 14 & BR74b & + & 2 & + & + & + & - & + & + & + \\
\hline 15 & BR49b & + & $1^{\mathrm{a}}$ & + & + & + & + & - & + & $t^{b}$ \\
\hline 16 & BR49c & + & 1 & + & + & + & + & - & + & $++^{b}$ \\
\hline
\end{tabular}

agene size: coa: 1 (600 bp), 2 (900 bp), bspa X region: (100bp).

AFLP was performed using basic PCR combined with a restriction enzyme and a DNA ligase to cut the genome at specific sites and ligate it with the appropriate adapter using a restriction enzyme (Janssen et al., 1996). This study used the primer HI-G (ATG GGT AGC TTG CGA CAG) as used by previous investigations (Boerema et al., 2006; Salasia et al., 2011). To compare the results of the AFLP analysis, we used $10 \mathrm{~S}$. aureus isolates from dairy cows in Yogyakarta (SU2, SU10, SU24, SU25 SU16, and SU28), Solo (SU34 and SU39) and Boyolali (BY5 and BY7) that had been previously generated by
Salasia et al. (2011). These data were used to unravel the relationship between isolates from Baturraden and those from the other regions (Figure 2).

The dendrogram in Figure 2 shows that $S$. aureus isolated from Baturraden group in one cluster, which has a similarity coefficient of $80 \%$. These isolates had a distant relationship with the ones collected from Yogyakarta and Solo, with a similarity coefficient of $62 \%$, but the Baturraden isolates had a closer relationship with those from Boyolali, with a similarity coefficient of $78 \%$. 


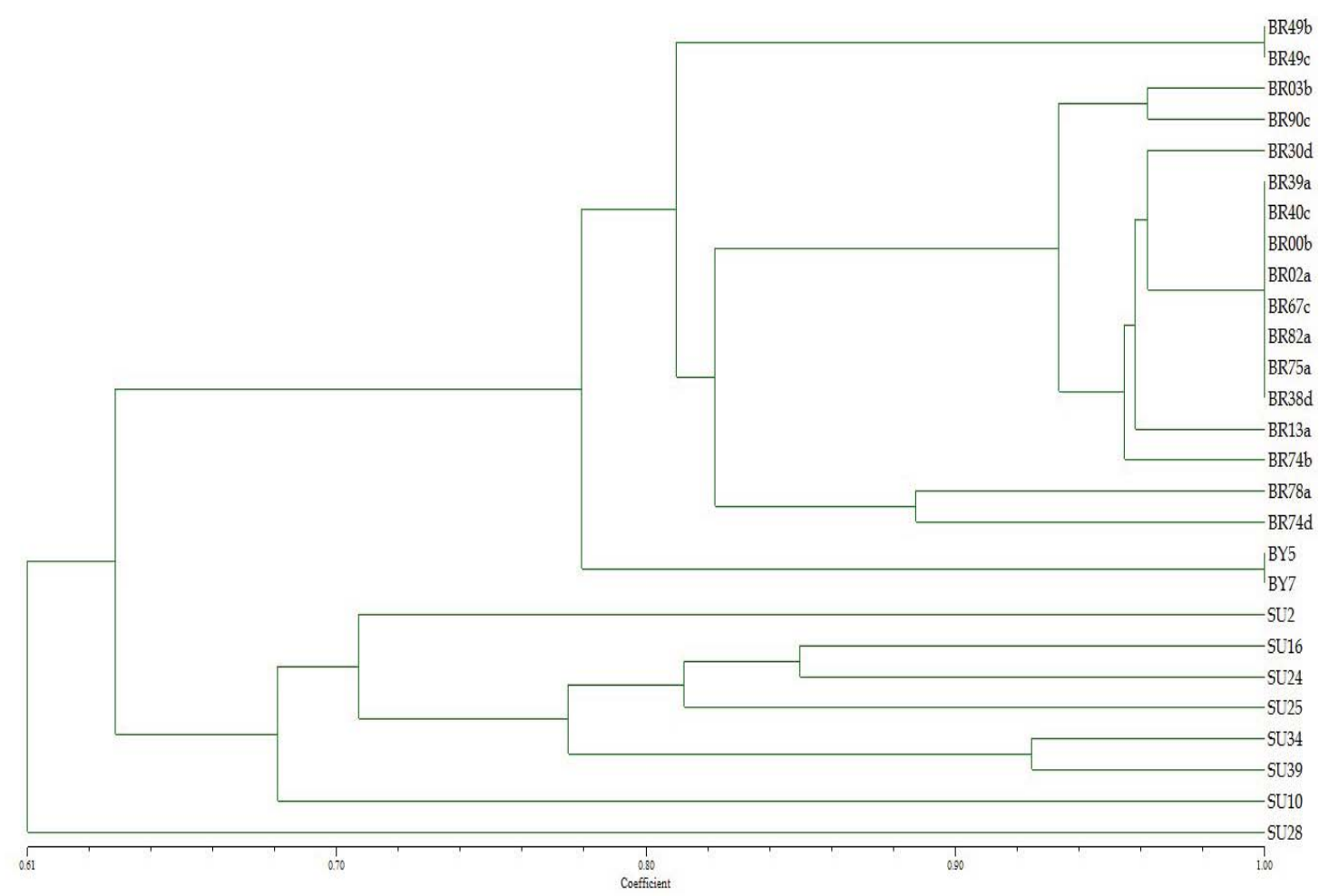

Figure 2. AFLP dendrogram analysis pattern showing relationship between 27 S. aureus isolates from dairy cows in Baturraden (BR), Yogyakarta (SU), Solo (SU) and Boyolali (BY) regions.

Clonal analysis of AFLP-based patterns of $S$. aureus originating from cows in Baturraden showed that there were similarities in some isolates, with values of the similarity coefficient of $100 \%$ (BR39a, BR40c, BR00b, BR02a, BR67c, BR82a, BR75a and BR38d). The results showed a close relationship between the $S$. aureus isolates originating from one location (cluster). $S$. aureus originating from Boyolali (BY5 and BY7), Solo and Yogyakarta showed different coefficients similarity, indicating the different origins of the isolates. Salasia et al. (2011) indicated that the clonal relationships between isolates of $S$. aureus are typically based on the origin of the isolates. Based on genotypic patterns of $S$. aureus strains, BR $49 \mathrm{~b}$ and $\mathrm{BR} 49 \mathrm{C}$ are genotypically different from the other isolates. It is interesting that these $S$. aureus strains had $100 \%$ coefficient similarity, the same coa gene size (600bp), and the same spa-X region gene size $(100 \mathrm{bp})$. Boerema et al. (2006) and Salasia et al. (2011) suggested that the variations in the characteristics of genotypic patterns of $S$. aureus are influenced by the relationship between the isolates, and that clustering isolates may be partly derived from a single progenitor (ancestor).

Results obtained in this study provide information and additional knowledge about $S$. aureus infection in Baturraden cows, including the number of virulence determinant genes that may play a role in pathogenicity. We also present clonal relationship patterns among Baturraden isolates that could be important in trying to address the problems there.

\section{Acknowledgments}

This research was support by Research Grant Partnership 2012 financed by DIKTI. We would like to thank Balai Besar Pembibitan Ternak Unggul (BBPTU), Baturraden, for research collaboration. 


\section{References}

Agus, M. 1991. Mastitis study in dairy cows in Baturraden. Hemerazoa. 74: 21-24.

Ariyanti, D., Salasia, S. I. O. and Tato, S. 2011. Characterization of haemolysin of Staphylococcus aureus isolated from food of animal origin. Indonesian Journal of Biotechnology, 16(1): 32-37.

Atkins, K.L., Burman, J.D., Chamberlain, E.S., Cooper, J.E., Poutrel, B., Bagby, S., Jenkins, A.T., Feil, E.J., van den Elsen, J.M. 2008. S. aureus IgG-binding proteins SpA and Sbi: host specificity and mechanisms of immune complex formation. Mol. Immunol. 45:1600-1611.

Boerema, J. A., Clemens, R. and Brightwell, G. 2006. Evaluation of molecular methods to determine enterotoxigenic status and molecular genotype of bovine, ovine, human and food isolates of Staphylococcus aureus. International Journal of Microbiology, 107: 192-201.

Cavalli, S., Forza, L. L. and Balfouier. 1997. Phylogenetic Analysis: Model and Estimation Procedures. Am. J. Human Genet. 19: 122-257.

Cheng, A. G., McAdow, M., Kim, H. K., Bae, T., Missiakas, D. M. and Schneewind, O. 2010. Contribution of coagulases towards Staphylococcus aureus disease and protective immunity. PLoS pathogens, 6(8), e1001036.

da Silva, E. R. and da Silva, N. 2005. Coagulase gene typing of Staphylococcus aureus isolated from cows with mastitis in southeastern Brazil. Canadian journal of veterinary research, 69(4), 260.

Halasa, T., Huijps, K., Østerås, O., \& Hogeveen, H. 2007. Economic effects of bovine mastitis and mastitis management: A review. Veterinary Quarterly, 29(1), 1831.

Janssen, P., Coopman, R., Huys, G., Swings, J., Bleeker, M., Vos, P., Zabeau, M. and Kersters, K. 1996. Evaluation of the DNA fingerprinting method AFLP as a new tool in bacterial taxonomy. Microbiology, 142:1881-93.
McDevitt, D., Francois, P., Vaudaux, P. and Foster, T.J. 1994. Molecular characterization of the clumping factor (fibrinogen receptor) of Staphylococcus aureus. Mol. Microbiol. 11:237-48.

Melles, D. C., Schouls, L., Francois, P., Herzig, S., Verbrugh, H. A., Van Belkum, A. and Schrenzel, J. 2009. High-throughput typing of Staphylococcus aureus by amplified fragment length polymorphism (AFLP) or multi-locus variable number of tandem repeat analysis (MLVA) reveals consistent strain relatedness. European journal of clinical microbiology $\mathcal{E}$ infectious diseases, 28(1), 39-45.

Nashev, D., Toshkava, K., Salasia, S.I.O, Hassan, A.A., Lammler, C., Zschock, M. 2004. Distribution of virulence genes of Staphylococcus aureus isolated from stable nasal carriers. FEMS Microbiol Lett. 233: 45-52.

Nielsen, C. 2009. Economic Impact Of Mastitis in Dairy Cow. Doctoral Thesis in Swedish University of Agricultural Sciences Uppsala.

O'Riordan, K. and Lee, J. C. 2004. Staphylococcus aureus Capsular Polysaccharides. Clin Microbiol Rev. 17(1): 218-34.

Pratomo, F. P., Salasia, S. I. O., \& Tato, S. 2012. Determination of Haemaglutinin and Gene Encoding Fibronectin Binding Proteins Staphylococcus aureus Isolated from Dairy Milk Cows. Indonesian Journal of Biotechnology, 16(2): 88-92.

Saei, H. D., Ahmadi, M., Mardani, K. and Batavani, R. A. 2009. Molecular typing of Staphylococcus aureus isolated from bovine mastitis based on polymorphism of the coagulase gene in the north west of Iran. Veterinary microbiology, 137(1), 202-206.

Salasia, S. I. O., Khusnan, Z. and Sidna. A. 2004. Distribution of cap5 and cap8 genes of Staphylococcus aureus isolated from subclinical mastitis cows in central Jawa, Indonesia. Indonesian Journal of Biotechnology.681-720

Salasia, S. I. O., Khusnan, Z., Lammler, C. and Zschock, M. 2004. Comparative studies 
on pheno-and genotypic properties of Staphylococcus aureus isolated from bovine subclinical mastitis in central Java in Indonesia and Hesse in Germany. J Vet Sci. 5 (2): 103-109.

Salasia, S. I. O., Tato, S., Sugiyono, N., Ariyanti, D. and Prabawati, F. 2011. A Genotypic characterization of Staphylococcus aureus isolated from bovines, humans and food in Indonesia. J. Vet. Sci. 12(4): 353-361.

Straub, J. A., Hertel, C. and Hammes, W. P. 1999. A 23S rDNA-Targeted Polymerase Chain Reaction-Based System for Detection of Staphylococcus aureus in Meat Starter Cultures and Dairy Products. J. Food Prot. 62:1150-1156.

Tato, S. 2012. Resistensi Staphylococcus aureus Terhadap Metisilin Serta Hubungan Pola Genetik antara Isolat Sapi Perah dan Manusia. Veterinary Science Desertation, Gadjah Mada University. 